Meals in the Early Christian World 
This page intentionally left blank 


\title{
Meals in the Early Christian World
}

\section{Social Formation, Experimentation, and Conflict at the Table}

\author{
Edited by \\ Dennis E. Smith and Hal E. Taussig
}




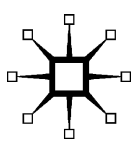

MEALS IN THE EARLY CHRISTIAN WORLD

Copyright (C) Dennis E. Smith and Hal E. Taussig, 2012

Softcover reprint of the hardcover 1st edition 2012 978-1-137-00288-4

All rights reserved.

First published in 2012 by

PALGRAVE MACMILLAN ${ }^{\circledR}$

in the United States-a division of St. Martin's Press LLC,

175 Fifth Avenue, New York, NY 10010.

Where this book is distributed in the UK, Europe and the rest of the world, this is by Palgrave Macmillan, a division of Macmillan Publishers Limited, registered in England, company number 785998, of Houndmills, Basingstoke, Hampshire RG21 6XS.

Palgrave Macmillan is the global academic imprint of the above companies and has companies and representatives throughout the world.

Palgrave ${ }^{\circledR}$ and Macmillan ${ }^{\circledR}$ are registered trademarks in the United States, the United Kingdom, Europe and other countries.

ISBN 978-1-349-43403-9 ISBN 978-1-137-03248-5 (eBook)

DOI $10.1057 / 9781137032485$

All photographs used with the permission of the photographers.

Figures 3.2, 3.3, 3.4, 3.5, and 3.6 used with permission from Superintendant Teresa Elena Cinquantaquattro of the Ministero per i Beni e le Attività Culturali, Soprintendenza Speciale per i Beni Archeologici di Napoli e Pompei.

Library of Congress Cataloging-in-Publication Data

Meals in the early Christian world : social formation, experimentation, and conflict at the table / edited by Dennis E. Smith and Hal E. Taussig. p. $\mathrm{cm}$.

Includes bibliographical references (p. ) and index.

1. Dinners and dining-Religious aspects-Christianity-History. 2. Dinners and dining-Greece-History. 3. Dinners and diningRome-History. I. Smith, Dennis Edwin, 1944- II. Taussig, Hal.

BR115.N87M43 2012

394.1'250938-dc23

A catalogue record of the book is available from the British Library.

Design by Newgen Imaging Systems (P) Ltd., Chennai, India.

First edition: December 2012

109876543321 


\section{Contents}

List of Figures vii

Abbreviations $\quad$ ix

Introduction 1

Hal E. Taussig

Part I The Typology of the Greco-Roman Banquet

Chapter 1 A Typology of the Communal Meal 9

Matthias Klinghardt

Chapter 2 The Greco-Roman Banquet as a Social Institution

Dennis E. Smith

\section{Part II The Archeology of the Banquet}

Chapter 3 What Kinds of Meals Did Julia Felix Have? A Case Study of the Archeology of the Banquet

Carolyn Osiek

\section{Part III Who Was at the Greco-Roman Banquets?}

Chapter 4 Social and Political Characteristics of Greco-Roman Association Meals

Richard S. Ascough

Chapter 5 Banqueting Values in the Associations: Rhetoric and Reality

Philip A. Harland

Chapter 6 Women in Early Christian Meal Gatherings:

Discourse and Reality

Angela Standhartinger 
Chapter 7 Remembering and Remembered Women

in Greco-Roman Meals

Ellen Bradshaw Aitken

Chapter 8 Present and Absent: Women at Greco-Roman

Wedding Meals

Susan Marks

Chapter 9 Evidence for Slaves at the Table in the Ancient

Mediterranean: From Traditional Rural Festivals

to Urban Associations

Nancy A. Evans

Chapter 10 The Sex Trade and Slavery at Meals

Carly Daniel-Hughes

Chapter 11 The Saturnalia in Greco-Roman Culture

Angela Standhartinger

Chapter 12 Early Christian Meals and Slavery

Lillian I. Larsen

Chapter 13 Slaves at Greco-Roman Banquets: A Response Jennifer A. Glancy

\section{Part IV The Culture of Reclining: Corporeality, Sexuality, Intimacy}

Chapter 14 Bodies in Motion, Bodies at Rest: Status, Corporeality, and the Negotiation of Power at Ancient Meals

Carly Daniel-Hughes

Chapter 15 Temptations of the Table: Christians Respond to Reclining Culture

Jennifer A. Glancy

Chapter 16 A Valentinian Response to the Culture of Reclining Ellen Bradshaw Aitken

Chapter 17 Monastic Meals: Resisting a Reclining Culture Lillian I. Larsen

Chapter 18 Inclined to Decline Reclining? Women, Corporeality, and Dining Posture in Early Rabbinic Literature

Jordan D. Rosenblum

Bibliography

List of Contributors

Subject Index

Index of Works Cited 


\section{Figures}

Front Cover: Banquet scene in the stibadium dining style, from a 3rd century CE mosaic, Sepphoris. Photo by Dennis Smith.

2.1 Greek dining diagram. () Dennis Smith. Reprinted with permission from From Symposium to Eucharist, 16.

2.2 Roman dining diagram. (C) Dennis Smith. Reprinted with permission from From Symposium to Eucharist, 17.

3.1 Julia Felix complex, Pompeii. Plan by C. Osiek.

3.2 Julia Felix complex, Pompeii. Room 6 biclinium. Photo by David Balch.

3.3 Julia Felix complex, Pompeii. Area 12. Photo by Carolyn Osiek.

3.4 Julia Felix complex, Pompeii. Room 16. Photo by David Balch.

3.5 Julia Felix complex, Pompeii. Room 40. Photo by David Balch.

3.6 Julia Felix complex, Pompeii. Room 40. Photo by David Balch.

3.7 Stone-carved stibadium for reclining. St. Agatha Catacomb, Malta. Photo by Carolyn Osiek.

3.8 Stone-carved benches. St. Agatha Catacomb, Malta. Photo by Carolyn Osiek. 
This page intentionally left blank 


\section{Abbreviations}

$\begin{array}{ll}\text { AGRW } & \text { Associations in the Greco-Roman World, ed. Ascough, } \\ \text { AION } & \text { Harland, and Kloppenborg } \\ \text { AJP } & \text { Annali dell'Instituto Orientale di Napoli } \\ \text { Anc. Soc. } & \text { American Journal of Philology } \\ \text { AThR } & \text { Ancient Society } \\ \text { BAR } & \text { Anglican Theological Review } \\ \text { BCH } & \text { Biblical Archaeology Review } \\ \text { BJS } & \text { Bulletin de correspondance hellénique } \\ \text { CCSL } & \text { Brown Judaic Studies } \\ \text { CIL } & \text { Corpus Christianorum: Series latina } \\ \text { CurBS } & \text { Corpus inscriptionem latinarum } \\ \text { CW } & \text { Currents in Research: Biblical Studies } \\ \text { EPRO } & \text { Classical World } \\ & \text { Études préliminaires aux religions orientales dans l'empire } \\ \text { FGH } & \text { romain } \\ \text { GR } & \text { Die Fragmente der griechischen Historiker, ed. F. Jacoby } \\ \text { HSCP } & \text { Greece and Rome } \\ \text { HTR } & \text { Harvard Studies in Classical Philology } \\ \text { HTS } & \text { Harvard Theological Review } \\ \text { HUCA } & \text { Harvard Theological Studies } \\ \text { Inscr. Erythrai } & \text { Hebrew Union College Annual } \\ \text { Engelmann \& Merkelbach, Die Inschriften von Erythrai } \\ \text { IFayum } & \text { und Klazomenai } \\ \text { ILS } & \text { Bernand, Inscriptions grecques du Fayoum. } \\ \text { IPerg } & \text { Inscriptiones graecae } \\ \text { JAAR } & \text { Inscriptiones Latinae Selectae } \\ & \text { Fränkel, Die Inscriften von Pergamon } \\ & \text { Journal of the American Academy of Religion }\end{array}$


$J A C$

$J d I$

JECS

JFSR

JHS

JJS

$J O ̈ A I$

$J Q R$

$J R A$

$J R S$

JSNT

JTS

L. A. B.

LCL

MMA

NGSL

NTOA

OGIS

PUP

P.Coll Youtie

PColon

PCPS

P. dem. Berlin

P. dem. Cairo

P. dem. Lille

P. dem. Prag.

P. Fouad

PG

PLond

P. Mert.

PMich

POxy

PPM

PW
Jahrbuch für Antike und Christentum

Jahrbuch des deutschen archäologischen Instituts

Journal of Early Christian Studies

Journal of Feminist Studies in Religion

Journal of Hellenic Studies

Journal of Jewish Studies

Jahreshefte des österreichischen archäologischen Instituts in Wien

Jewish Quarterly Review

Journal of Roman Archaeology

Journal of Roman Studies

Journal for the Study of the New Testament

Journal of Theological Studies

Liber Antiquitatum Biblicarum of Pseudo-Philo

Loeb Classical Library

Metropolitan Museum of Art

Lupu, Greek Sacred Law

Novum Testamentum et Orbis Antiquus

Orientis graeci inscriptiones selectae

Past and Present

Collectanea Papyrologica: Texts Published in Honor of H.C.

Youtie

Kölner Papyri

Proceedings of the Cambridge Philological Society

Spiegelberg, Demotische Papyrus aus den königlichen Museen zu Berlin

Spiegelberg, Catalogue général des Antiquités égyptiennes du Musée du Caire

Sottas, Papyrus démotiques de Lille

Erichsen, Die Satzungen einer ägyptischen Kultgnossenschaft aus der Ptolemäerzeit

Les Papyrus Fouad I, ed. P. Jouguet

Patrologia graeca

Skeat, Zenon Archive.

Rees, Bell, \& Barns, A Descriptive Catalogue of the Greek Papyri in the Collection of Wilfred Merton II

Boak, Papyri from Tebtunis.

Oxyrhynchus papyri

Pompeii, pitture e mosaici, ed. Ida Baldassare et al.

Pauly \& Wissowa, Realencyclopädie der classischen Altertumswissenschaft 
1QS Rule of the Community (Dead Sea Scrolls)

REA Revue des études anciennes

RevPhil Revue de philologie

SBLDS Society of Biblical Literature Dissertation Series

SIG Sylloge inscriptionum graecarum

StPatr Studia Patristica

TANZ Texte und Arbeiten zum neutestamentlichen Zeitalter

TAPA Transactions of the American Philological Association

Vg Vulgate

WUNT Wissenschaftliche Untersuchungen zum Neuen Testament 